\title{
Taxonomy of the New World bee genus Agapostemon Guérin-Méneville - new names and synonymies (Hymenoptera: Halictidae)
}

\author{
Cory S. SHEFFIELD ${ }^{1, *}$, Lars VILHELMSEN ${ }^{2} \&$ Frederique BAKKER $^{3}$ \\ ${ }^{1}$ Royal Saskatchewan Museum, 2340 Albert Street, Regina, Saskatchewan S4P 2V7 Canada. \\ ${ }^{2}$ Natural History Museum of Denmark, Science, University of Copenhagen, \\ Universitetsparken 15, DK-2100 Copenhagen, Denmark. \\ ${ }^{3}$ Naturalis Biodiversity Center, Darwinweg 2, 2333 CR Leiden, Netherlands. \\ *Corresponding author: Cory.Sheffield@gov.sk.ca \\ ${ }^{2}$ Email: lbvilhelmsen@snm.ku.dk \\ ${ }^{3}$ Email: frederique.bakker@naturalis.nl \\ $1 \odot$ https://orcid.org/0000-0003-0603-7333 \\ $2 \odot$ https://orcid.org/0000-0002-5593-5722 \\ ${ }^{1}$ urn:1sid:zoobank.org:author:E8A20492-60B0-411E-A119-99A6A7F16C15 \\ ${ }^{2}$ urn:lsid:zoobank.org:author:96FC3783-9FA7-421E-B292-6718A3762D45 \\ ${ }^{3}$ urn:lsid:zoobank.org:author:F43869DC-20F9-4ED2-A37D-4A3282B1D2BD
}

\begin{abstract}
Many early taxonomic works on North American bees were published by Europeans using specimens collected in the New World, some with type locations so imprecise that uncertainty on the nomenclatural status remains to this day. Two examples come from Fabricius (1745-1808) who described Andrena virescens Fabricius, 1775 and Apis viridula Fabricius, 1793 from "America" and "Boreal America", respectively. The former species of Agapostemon Guérin-Méneville, 1844 occurs across most of the United States and southern Canada, the latter presumed an endemic to Cuba. The type materials of these two taxa have never been compared to each other, though a morphology-based phylogenetic analysis placed both in distinct species groups. Here we synonymize Apis viridula under Ag. virescens, thereby making Ag. femoralis (Guérin-Méneville, 1844) available as the name for the Cuban species. A lectotype for Ag. femoralis (the type species for the genus Agapostemon) is hereby designated to stabilize this taxonomy. We also synonymize $A g$. obscuratus Cresson, 1869 under Ag. femoralis, suggesting that it represents a dark colour polymorphism. As Ag. cubensis Roberts, 1972 is a junior secondary homonym of $\mathrm{Ag}$. cubensis (Spinola, 1851), we offer $\mathrm{Ag}$. robertsi as a replacement name for the former.
\end{abstract}

Keywords. Bees, lectotype, North America, the Antilles.

Sheffield C.S., Vilhelmsen L. \& Bakker F. 2021. Taxonomy of the New World bee genus Agapostemon GuérinMéneville - new names and synonymies (Hymenoptera: Halictidae). European Journal of Taxonomy 751: 1-23. https://doi.org/10.5852/ejt.2021.751.1375 


\section{Introduction}

Much past confusion has surrounded the nomenclatural status of the North American sweat bee Agapostemon virescens (Fabricius, 1775) (Hymenoptera: Halictidae) largely due to the fact that, pre1900, many taxonomists naming material from the New World were from Europe (e.g., Fabricius 1775, 1793; Lepeletier 1841; Smith 1853; Dalla Torre 1896) and vague or imprecise collection information was recorded for much of this material, including the type localities. Andrena virescens Fabricius, 1775 was named from material collected in "America" (Fabricius 1775); this species is widespread across most of the United States and southern Canada (Roberts 1972), but seemingly is not found in Mexico or Mesoamerica (Roberts 1972; Roberts \& Brooks 1987; Ramírex-Freire et al. 2012); the few specimens identified from Mexico, Honduras (det. by W.E. LaBerge), and Cuba (St. Clara) (see Ascher \& Pickering 2020) may represent misidentifications. The latter is especially interesting as it likely represents a specimen of $A g$. viridulus (Fabricius, 1793), a species now considered to be a Cuban endemic (Moure 1960; Roberts 1972; Moure et al. 2007).

Cresson (1887) was the first North American to apply a name currently associated with Ag. virescens to this taxon, recognizing Ag. nigricornis (Fabricius, 1793) as a valid species, likely following the classification of Smith (1853); a more specific type locality of Georgia was provided for this taxon by Fabricius (1793), though Cresson (1887) also indicated that this species may be a synonym of Ag. sericeus (Forster, 1771). Soon after, several works on North American bees applied the name Ag. viridulus, and not the older Ag. virescens, to material collected in the United States and Canada, including Robertson (1895, 1897), Titus (1900), Crawford (1901, 1906 (in Viereck et al. 1906), 1912), Vachal (1903), Cockerell (1902, 1904, 1909, 1911), Shelford (1913, 1937), Stevens (1920), and Tucker (1909). Cockerell (1917a) later described Ag. tyleri Cockerell, 1917 from Mexico, but indicated that it was almost exactly like $A g$. viridulus.

The name Ag. viridulus was likely applied to North American material because Robertson (1897) stated that "it is an absurd affection of authority to give this name [i.e., $\mathrm{Ag}$. viridulus] to the Cuban species, before it is shown that Fabricius did not mean that his species came from the continent of North America, that he did not know where it came from, or that the description of Apis viridula does not apply to the North American species". In his study of Cuban bees, Baker (1906) expressed sentiments similar to those of Robertson (1897) on Ag. viridulus as a valid species in Cuba. Fabricius (1793) did not provide a type locality for $\mathrm{Ag}$. viridulus in his original work, but in 1804 indicated that the species (as Megilla viridula) was from "Habitat in America boreali" (Fabricius 1804) which Robertson (1897) considered to mean North America. Robertson (1897) also indicated that Provancher (1882) likely misidentified Ag. viridulus (=Ag. virescens) as Augochlora radiata (= Ag. sericeus (Forster, 1771)) based on the black metasoma (this misidentification was confirmed by Sheffield \& Perron 2014), though in that same work he (i.e., Provancher 1882) recognized Ag. tricolor Lepeletier, 1841 (= Ag. virescens) as a distinct species. Crawford (1912) later used Ag. viridulus for specimens from Medicine Hat, Alberta, and the name $\mathrm{Ag}$. virescens did not appear in his earlier revision of North American species (Crawford 1901), though again the morphology and geography fit the current concept for this species (i.e., Roberts 1972). Though Ag. virescens is the oldest name for this taxon, Robertson (1897) and later authors did not consider $A g$. viridulus a synonym of $A g$. virescens presumably because Fabricius (1804) provided more precise type location information. However, Ag. virescens is now widely recognized as the only member of the genus occurring in eastern North America and all of Canada in which the female has the combination of a black metasoma (Sandhouse 1936; Roberts 1972; Packer et al. 2007) and dark-tipped clypeus.

Ashmead (1900) was among the first American entomologists to consider Ag. viridulus a Cuban species, likely based on the earlier opinion of Dalla Torre (1896), in contrast to the earlier opinion of Robertson (1897) quoted above. Dalla Torre's (1896) concept was subsequently followed by Friese (1902), with 
both considering Ag. femoralis Guérin-Méneville, 1844 a synonym of $A g$. viridulus. The lectotype for Ag. viridulus was designated by Moure (1960) from two female specimens at the Sehested - Tønder Lund collection at the Zoologisk Museum in Copenhagen; Moure (1960) indicated that the species was apparently limited to Cuba, and provided a brief description but offered no diagnosis to separate this material from the more common and widespread North American species Ag. virescens despite the past controversy. Roberts (1972) accepted the treatment of Moure (1960), but indicated that due to the inadequacy of the original description, many authors believed that $A g$. viridulus was a synonym of Ag. virescens. Almost 50 years later, Ag. viridulus is still considered an endemic to Cuba (e.g., Roberts 1972; Janjic \& Packer 2003; Engel 2004; Genaro 2008). The male specimen of Ag. femoralis that Ashmead (1896, and subsequently Krombein 1953) recorded from Eleuthera, Bahamas was presumably misidentified; however, several other species are known from the Bahamas (Roberts 1972; Janjic \& Packer 2003).

Another Cuban endemic, Ag. obscuratus Cresson, 1869 has also contributed to the confusion. At the time of describing Ag. obscuratus, Cresson (1869) first thought it was likely only a variety of Ag. femoralis ( $=A g$. viridulus), but later indicated it was a distinct species, supporting the opinion of J.C. Gundlach (as cited in Cresson 1869); subsequently, Gundlach (1896) still considered it a distinct Cuban species. In fact, Cresson (1865) indicated that two of the 40 male specimens identified as $\mathrm{Ag}$. femoralis that he examined had the head and thorax dull black with very faint obscure blue colouration, matching what he would later (i.e., Cresson 1869) call Ag. obscuratus. Oddly, Cresson (1869) compared what he indicated as a female to the male of Ag. femoralis; Roberts (1972) correctly pointed out that the type materials of both taxa are male. Cockerell (1917b) seemingly made the same mistake for his Ag. obscuratus var. abjectus Cockerell, 1917, and also indicated that it was close to Ag. femoralis, but larger with the head and thorax coloured differently (i.e., obscurely dark green head and thorax in Ag. obscuratus abjectus) from Cresson's taxon that had the head and thorax black, with a more or less purple tinge. Since the last comprehensive revision (i.e., Roberts 1972), Ag. obscuratus has been considered a valid taxon.

Though the genus Agapostemon Guérin-Méneville, 1844 has received taxonomic treatment several times (e.g., Crawford 1901; Sandhouse 1936; Fischer 1950; Roberts 1972, 1973), only Roberts (1972) provided a comprehensive review of the genus throughout its entire range. Unfortunately, Roberts (1972) treated the species in a series of regional keys, and no comparisons were made that included both Ag. virescens and Ag. viridulus. However, Janjic \& Packer (2003) produced a morphology-based phylogeny in which all species were included, including material from Cuba identified as Ag. viridulus and $A g$. obscuratus. Although $A g$. virescens and $A g$. viridulus are seemingly very similar (Roberts 1972), the results of Janjic \& Packer (2003) clearly separated the two species, enough that they were placed in two different species groups, the latter belonging to a species group restricted to the Antilles which also contained Ag. obscuratus. Unfortunately, type material for all species was not compared and/ or used in that phylogenetic analysis, so they (i.e., Janjic \& Packer 2003) used the taxonomic concepts of Roberts (1972; with some exceptions). Our purpose here is to clarify the taxonomy of Ag. virescens and Ag. viridulus.

\section{Material and methods}

Using the morphology-based matrix of Janjic \& Packer (2003) as a guide, female specimens of Ag. virescens from throughout North America were examined for morphological consistency with the holotype (Fig. 1) and compared with the lectotype of $A g$. viridulus (Fig. 2). The phylogeny of Janjic \& Packer (2003) placed these two species into two morphologically unique species groups; those characters considered most useful (i.e., unique species specific character states) for distinguishing Ag. virescens from $A g$. viridulus albeit chosen so not to damage Fabricius's types (i.e., not requiring dissection or relaxation of the specimens to permit movement of body parts) were compared, in addition to more 
general morphological features discussed below. The type material of Ag. femoralis (Fig. 3) and photos of the type material of Ag. semiviridis Cresson, 1865 (Fig. 4), Ag. obscuratus (Fig. 5), and Ag. obscuratus var. abjectus Cockerell, 1917 (synonymized under Ag. obscuratus by Roberts 1972) (Fig. 6) were also examined; $\mathrm{Ag}$. femoralis and $\mathrm{Ag}$. semiviridis were previously synonymized under $\mathrm{Ag}$. viridulus by Dalla Torre (1896) and Baker (1906), respectively, though the latter is the only taxon currently synonymized under Ag. viridulus that is from Cuba that has a female type specimen.

Morphological terminology generally follows that of Michener (2007), with some specific terms from Roberts (1972); surface sculpture terminology follows Harris (1979). Face length to width (L:W) ratios were calculated using the following: $\mathrm{L}=$ distance from lower edge of median ocellus to the basal edge of clypeus; $\mathrm{W}=$ greatest distance between the inner edges of the compound eyes, measured at apex of angulation.

DNA barcodes (Hebert et al. 2003) were also compared, using Cytochrome Oxidase I (COI) sequences previously published by Sheffield et al. $(2009,2017)$, and for material identified as or sharing a Barcode Index Number (BIN, after Ratnasingham \& Hebert 2013) with Ag. viridulus from Cuba in the Barcodes of Life Data (BOLD) system (Ratnasingham \& Hebert 2007), this included a single specimen of Ag. obscuratus. Sequences were analyzed using the Barcode Gap Analysis tool on BOLD, using the Kimura 2 Parameter distance model with sequence alignment using MUSCLE. Using the same distance model and alignment parameters, nucleotides from sequences of a representative member of each BIN with a full DNA barcode were examined and compared.

The following acronyms are used for collections:

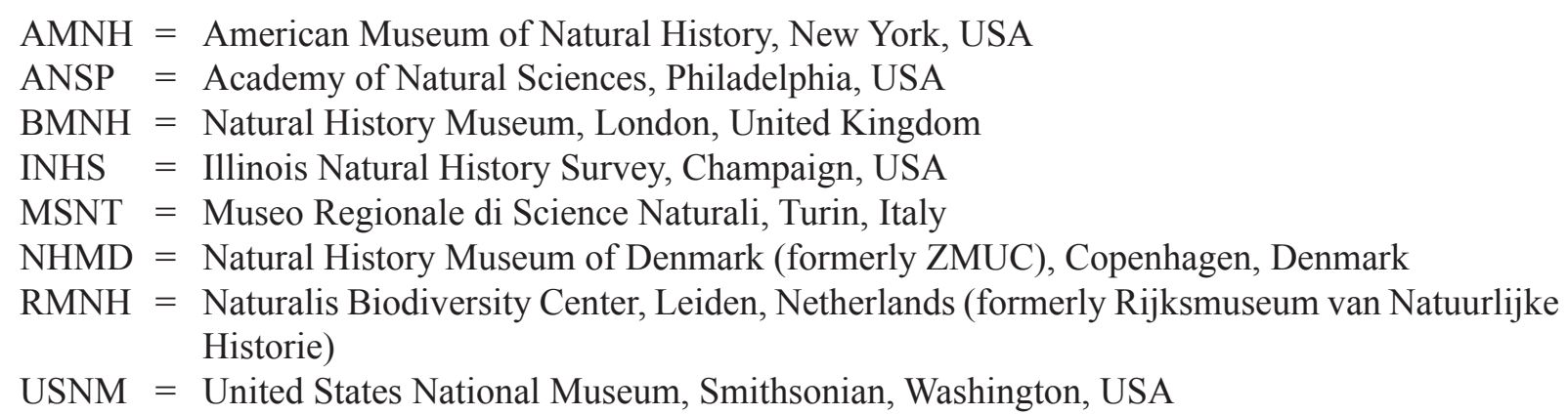

\section{Results}

Morphologically, the lectotype of $A g$. viridulus (Fig. 2) clearly matches Ag. virescens (in the splendens group of Moure \& Hurd 1987) and not Cuban material in the the viridulus group seemingly confined to the Antilles (Moure \& Hurd 1987; Janjic \& Packer 2003). In fact, the females of Ag. virescens, including the type material of $\mathrm{Ag}$. viridulus are quite different from material from Cuba, with specimens from the latter, including $A g$. obscuratus, having a longer face ( $\mathrm{L}: \mathrm{W}=0.78$, versus $0.72 \mathrm{in} A g$. virescens) (Fig. 7C, E; Roberts 1972: figs 33-34, 53-54), with prominent horizontal striations across most of the clypeus and supraclypeal area (Fig. 7C, E), while those of Ag. virescens and the type material of Ag. viridulus are coarsely and closely punctate, with striations limited to the medial area of supraclypeal area (Fig. 7A). Other morphological differences include the propodeal surface of $\mathrm{Ag}$. virescens and the type material of $A g$. viridulus, which is coarsely rugose, with the posterior surface of the propodeum encircled by a strong carina (Fig. 8A), while the surface is costulate to costate in Cuban material, including Ag. obscuratus, with the carina much less distinct, especially laterally (Fig. 8C).

Though males of Ag. virescens and Cuban material identified as Ag. viridulus were also not compared or keyed by Roberts (1972), they are distinctive. Males of Ag. virescens have extensive yellow maculations, 
including a more pronounced triangular mark on the clypeus apically that extends basad medially (Fig. 7B), while the clypeal maculation on Cuban material (Fig. 7D), including Ag. obscuratus (Fig. 7F) is linear. Most of the legs in male Ag. virescens are extensively yellow, with dark markings restricted to the outer basal area of the fore and mid femur, an elongate basal mark basally on the inner front tibia, two elongate marks on the inner and outer basally on the mid tibia, and the hind leg with dark spot at the apex of femur, a small basal spot and an elongate spot in the outer basal half of the tibia; the legs of Cuban males, including Ag. obscuratus are primarily dark with yellow areas restricted to the inner surfaces, and the basal half of hind femur; $A g$. virescens have the metasoma with a submedian yellow band on tergum 1, and extensive basal bands on terga 2-5 (Fig. 9A), while the metasoma of Cuban material is entirely dark (Fig. 9B-C). Structurally, the males of $A g$. virescens also have a shorter face $(\mathrm{L}: \mathrm{W}=0.72)$ (Fig. 7B) than material from Cuba (L:W =0.8) (Fig. 7D, F). In addition, the hind tibia and femur of $\mathrm{Ag}$. virescens are relatively narrow, less than half as wide as long, while more robust in Cuban material including Ag. obscuratus, the femur less than twice as long as wide (Figs 3C, 5A, 6A); the hind tarsi of Ag. virescens are unmodified (Fig. 10A) while the hind basitarsus of Cuban material has a prominent basal ridge and an apical groove (Fig. 10B; Roberts 1972: figs 150, 158). The propodeum of $\mathrm{Ag}$. virescens is coarsely rugose over its dorsal and lateral surfaces, with the posterior surface encircled by a strong carina (Fig. 8B), while males of Cuban material have a less distinctive carina (entirely lacking laterally), with the propodeal surfaces striate (Fig. 8D).

Based on our comparison of the type material of Ag. viridulus (Fig. 2) to female specimens of Ag. virescens from North America, including the holotype (Fig. 1), we conclude that the former is a synonym of the latter. As such, Ag. femoralis, with a type locality of Cuba (Fig. 3) would be the oldest name available for the Cuban species. We also rename the viridulus species group of Moure \& Hurd (1987) the femoralis species group to reflect this. We conclude that, though Robertson (1897) felt that Ag. viridulus was the priority name for the North American taxon, the type specimen of Ag. virescens matches North American material, and we assume that the type locality "America" referred to North America (the type material has previously even been labelled as such, see Fig. 1), as this specimen does not match other species outside of the continent (i.e., Central or South America, or the Antilles). This also stabilizes the taxonomy of a species that has been subject to many ecological and taxonomic studies (e.g., LaBerge \& Ribble 1966; Roberts 1972; Abrams \& Eickwort 1980, 1981; Eickwort \& Abrams 1980; Eickwort 1981).

The BIN for $A g$. virescens is AAB2708, and currently in BOLD there are 90 sequences from across Canada and the eastern United States; within this BIN the mean distance is $0.36 \%$, with a maximum distance of $1.48 \%$. There are two sequences (BOLD Process IDs BEECB084-07 and BEECB087-07) available for Ag. femoralis from Cuba (AAJ7225; the former of these identified as Ag. obscuratus Cresson, 1869), differing from that of $\mathrm{Ag}$. virescens by $12.1 \%$, with 86 nucleotide differences, and supporting that though these species are considered morphologically very similar (i.e., Roberts 1972), there is enough genetic and morphological divergence to distinguish these species. Though only a single specimen of each taxon was sequenced, barcoded material of $\mathrm{Ag}$. obscuratus, also from Cuba, is genetically almost identical to the sequence of $\mathrm{Ag}$. femoralis, differing in only one nucleotide at position 494 (A to C, respectively). In addition, apart from colour, the morphology of both taxa are identical, Ag. obscuratus abjectus (synonymized under Ag. obscuratus by Roberts 1972) representing an intermediate coloured form.

Lastly, Ag. cubensis Roberts, 1972 became a junior secondary homonym of Ag. cubensis (Spinola, 1851) when Engel (2004) designated a lectotype for the latter taxon and recognized it as a synonym of Ag. viridulus [ $=$ Ag. femoralis]. Roberts'taxon is known only from the male holotype (Roberts 1972), and since it was described the name has only been used in a handful of other publications (i.e., Alayo 1973, 1976; Janjic \& Packer 2003). Therefore, we offer Ag. robertsi as a replacement name for Ag. cubensis 
Roberts, named for the late Radclyffe Burnand Roberts (1938-1988) for his work on Agapostemon and other bees.

\section{Taxonomy}

Class Insecta Linnaeus, 1758

Order Hymenoptera Linnaeus, 1758

Family Halictidae Latreille, 1804

Subfamily Halictinae Latreille, 1804

Tribe Halictini Latreille, 1804

Subtribe Caenohalictina Cameron, 1903

Genus Agapostemon Guérin-Méneville, 1844

Andrena (Agapostemon) Guérin-Méneville, 1844a: 448. Type species: Apis femoralis Guérin-Méneville, 1844, monobasic.

Agapostemon virescens (Fabricius, 1775)

Figs 1, 7A-B, 8A-B, 9A

Andrena virescens Fabricius, 1775: 378 [].

Andrena nigricornis Fabricius, 1793: 313 [ð] [synonymy by Smith 1853: 86, though of Ag. virescens under Ag. nigricornis; synonymy of Ag. virescens by Dalla Torre 1896: 98].

Apis viridula Fabricius, 1793: 3742 []. syn. nov.

Halictus dimidiatus Lepeletier, 1841: 283 [ㅇ] [synonymy of Ag. virescens by Dalla Torre 1896: 98; of Ag. viridulus by Robertson 1897: 326].

Halictus tricolor Lepeletier, 1841: 289 [ ${ }^{\dagger}$ ] [synonymy of Ag. nigricornis by Cresson 1887: 293; synonymy of $A g$. virescens by Dalla Torre 1896: 98].

Agapostemon bicolor Robertson, 1893: 148 [ㅇ, §ె] [synonymy of Ag. viridula by Robertson 1895: 118; of Ag. virescens by Moure 1960: 103].

\section{Material examined}

\section{Holotype}

COUNTRY UNKNOWN • 1 q; “America”; BMNH(E) 668675.

See https://data.nhm.ac.uk/object/4dece8b7-ab26-4233-86c9-de79d6a80a91.

\section{Additional material}

COUNTRY UNKNOWN • 1 q (lectotype of Apis viridula Fabricius, 1793, designated by Moure 1960: 104); [Type locality not indicated in original work; "Habitat in America boreali" was indicated by Fabricius (1804)]; NHMD ZMUC00241490 (Fig. 2).

\section{Notes}

The location of the syntype $\delta$ of Andrena nigricornis Fabricius, 1793, from Georgia, is unknown, as per Sandhouse 1936: 77 and Moure 1960: 104. The same it true with the $q$ type of Halictus dimidiatus Lepeletier, 1841: "probablement de l'Amérique septentrionale" [Musée de M. Serville was indicated], and with the ${ }^{\lambda}$ type of Halictus tricolor Lepeletier, 1841: "Amérique septentrionale" [Musée de M. Serville was indicated, Roberts (1972) indicated Instituto e Musco de Zoologia, Universita di Torino, Italy].

The lectotype $q$ of Agapostemon bicolor Robertson, 1893 (designated by W.E. LaBerge in Webb 1980: 115) from USA, Illinois, Carlinville, 22 Sep. 1886, C.A. Robertson leg., INHS 3306, was not examined as the synonymy was not questioned. 

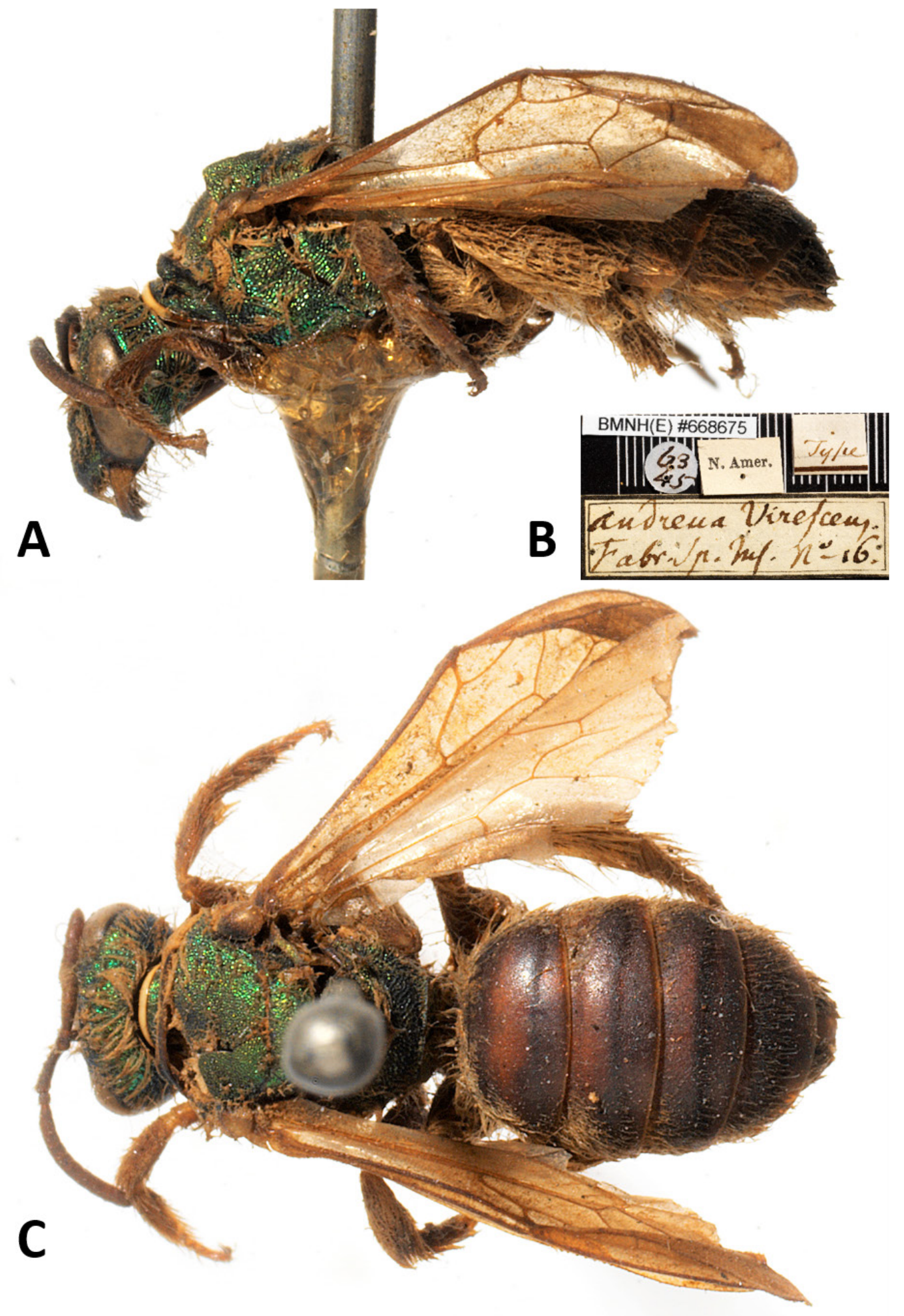

Fig. 1. Andrena virescens Fabricius, 1775. Holotype, $q$ (BMNH(E) 668675). A. Lateral view. B. Associated labels. C. Dorsal view. Photo credit: Natural History Museum, London (2020). Data Portal Query on "Specimens" https://doi.org/10.5519/qd.7pgn1j4u. Subset of "Collection specimens" (dataset) https://doi.org/10.5519/0002965. Layout modified from original. 


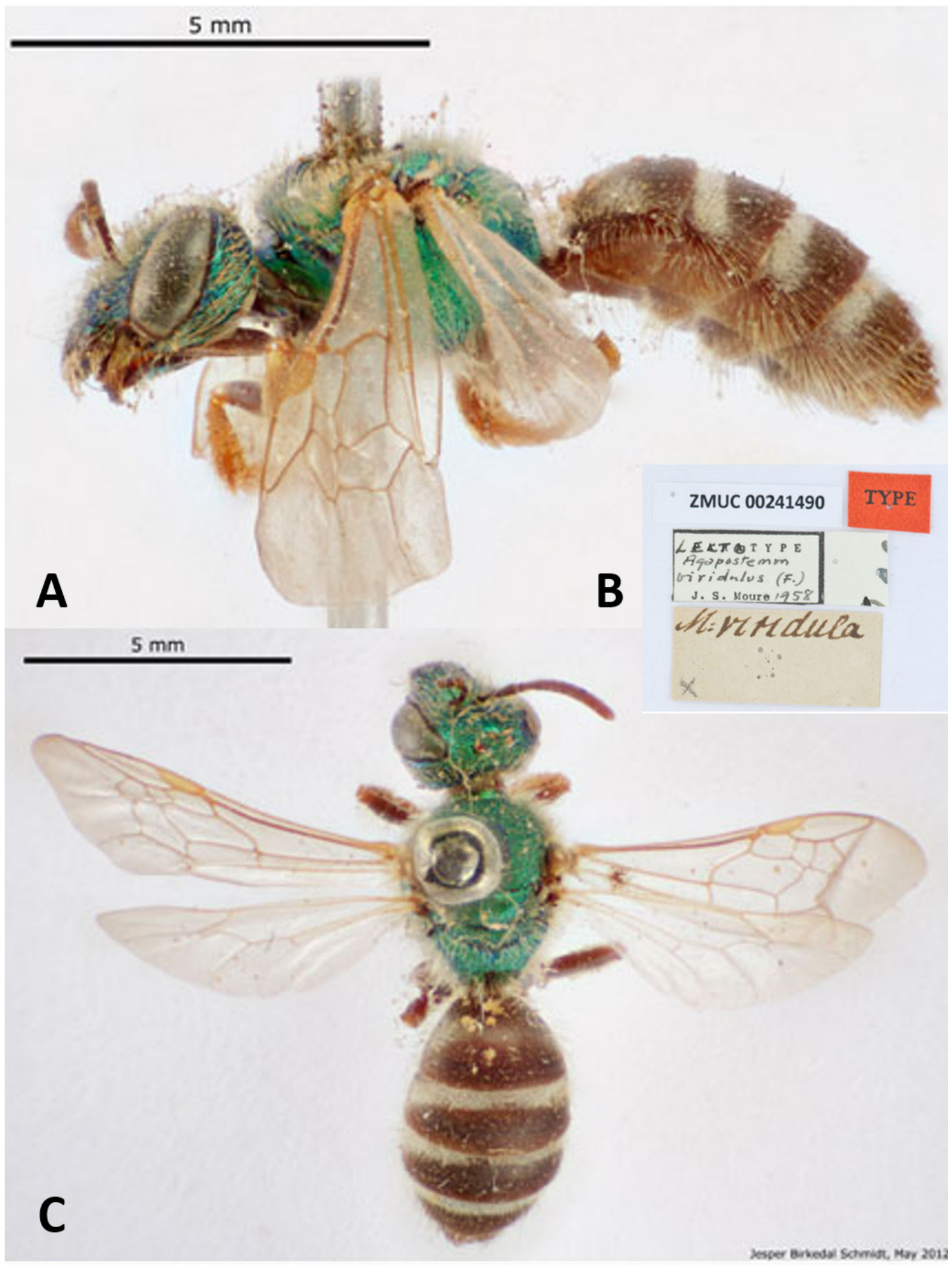

Fig.2.Apisviridula Fabricius, 1793.Lectotype,,+ (NHMDZMUC00241490).A.Lateralview.B.Associated labels. C. Dorsal view. Photos by Jesper Birkedal Schmidt, Natural History Museum of Denmark [digitized assets http://daim.snm.ku.dk/digitized-type-collection-details-simple?catno=zmuc00241490]. 


\section{Remarks}

Under his discussion of Ag. virescens, Cockerell (1921) included a brief mention of Apis vitreus, originally named and described from the male (with a colour illustration) by Harris (1782: pl 39 fig. 17); in the figure caption, Harris (1782) mentioned the brilliant green head and thorax, with yellow mouthparts, antennae, legs and abdomen, the latter with six black bands, which is consistent with most male Agapostemon in North America (e.g., Roberts 1972). Cockerell (1921) felt that this name should be considered valid, and presumably a synonym of Ag. virescens. As Harris's (1782) work was focused on the insects of England, Warncke (1973) considered it (as Apis vitreus Harris, 1776, from England) a synonym of Halictus tumulorum (Linnaeus, 1758). However, Ebmer (1974) considered Harris's taxon nomen dubium, indicating that the synonymy of Warncke (1973) was incorrect, and suggested that the large size of 11.5-12.5 mm (from Ebmer (1974), based on Harris's (1782) mention of "five lines and a half') and description supported that it was likely a male of Agapostemon, partially supporting Cockerell's (1921) opinion. Ebmer (1974) also indicated that it was likely that at the time of collection (i.e., pre-1776), the New England states (where it was presumably collected) were regarded as belonging to the "motherland" (i.e., England), though by the time of publication of Harris's works (i.e., 1776-1782) the United States was independent. However, as four species of Agapostemon with males generally matching that described by Harris (1782) are found in the New England states, we follow Ebmer's (1974) recommendation and consider Harris's species nomen dubium until the type material can be located.

"America" was indicated as the type locality for Ag. virescens by Fabricius (1775), but the type specimen has seemingly been re-labelled after the fact (i.e., post Cresson 1887) with N[orth]. Amer[ica]. (Fig. 1); the specimen was previously examined by Cockerell (1921) and later by Charles D. Michener (as per Roberts 1972) who both considered it a valid representation of this taxon. Smith (1853) considered Apis virescens Fabricius 1793 (not 1775) a synonym of Ag. nigricornis, presumably not realizing that the species had been named 18 years previous (though he attributed it to the Banks Collection, as is the type material).

Agapostemon femoralis (Guérin-Méneville, 1844) stat. nov.

Figs 3, 7D, 8D, 9B, 10B

Andrena (Agapostemon) femoralis Guérin-Méneville, 1844a: 447 [§̋].

Halictus cubensis Spinola, 1851: 203 [ô, not +] [synonymy of Ag. viridula by Engel 2004: 170].

Agapostemon semiviridis Cresson, 1865: 172 []] [synonymy of Ag. viridulus by Baker 1906: 274].

Agapostemon obscurata Cresson, 1869: 295 [ $\hat{0}$, not $q$ as indicated]. syn. nov.

Agapostemon obscuratus var. abjectus Cockerell, 1917b: 436 [0 , not + as indicated] [synonymy of Ag. obscuratus by Roberts 1972: 513].

Agapostemon viridualus -Janjic \& Packer, 2003: 109. Lapsus calami.

\section{Material examined}

Lectotype (designated here, Fig. 3)

CUBA • \} \text { ; Monchicourt leg.; RMNH.INS.1283531. }

\section{Additional material}

CUBA 1 1 (lectotype of Agapostemon semiviridis Cresson, 1865, designated by Cresson 1916: 109); ANSP 2788 (Fig. 4) 1 त (lectotype of Agapostemon obscurata Cresson, 1869, designated by Cresson 1916: 108); ANSP 2790 (Fig. 5) • 1 o (holotype of Agapostemon obscuratus var. abjectus Cockerell, 1917); Cabanas [Cabañas]; 28 May [no year provided]; Palmer and Riley leg.; USNM 22938 (Fig. 6). 


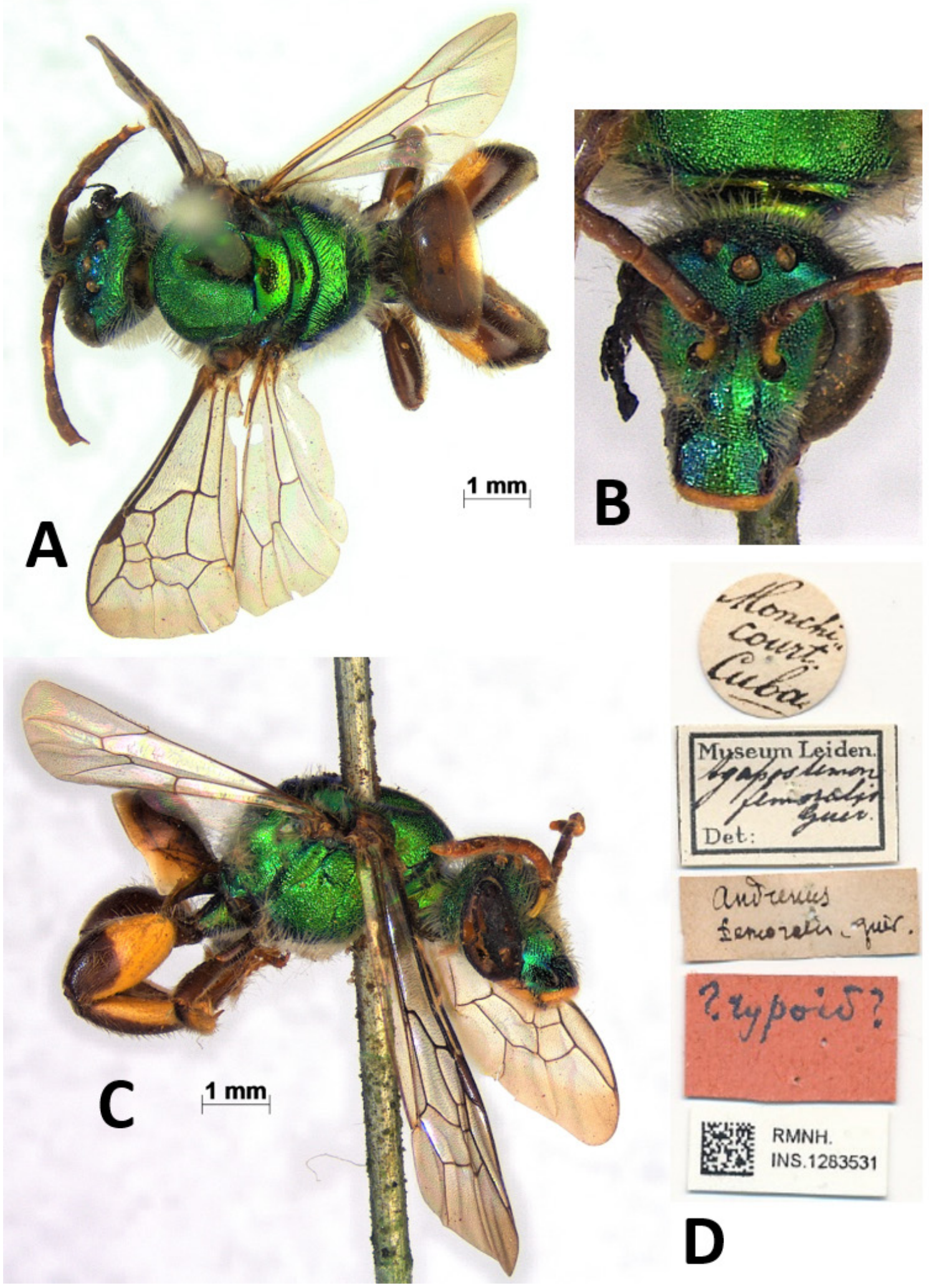

Fig. 3. Agapostemon femoralis Guérin-Méneville, 1844, the type species for the genus Agapostemon Guérin-Méneville, 1844. Lectotype (designated here), ô (RMNH.INS.1283531). A. Dorsal view. B. Face. C. Lateral view. D. Associated labels. Photos by F. Bakker, Naturalis Biodiversity Center. 


\section{Notes}

The lectotype $\delta$ of Halictus cubensis Spinola, 1851 (designated by Engel 2004: 170), from Cuba, Havana, Spinola Collection, MSNT, was not examined as the synonymy was not questioned.

\section{Remarks}

The name and description of Andrena femoralis is attributed to Guérin-Méneville (1844a), though the name (i.e., Andrena femoralis Guer.), type locality (i.e., Cuba) and first illustration appear on plate 83, figure 1 (incorrectly recorded as plate 73 by Van der Vecht 1957) for Cuvier's (1836) work published in 1837 (Cuvier 1837). These images were later duplicated in Guérin-Méneville (1844b) as "Insectès, PI[ate]. 73, Figure 1". Banks (1909) commented on the dates of Guérin-Méneville's Iconographie du Regne Animali,

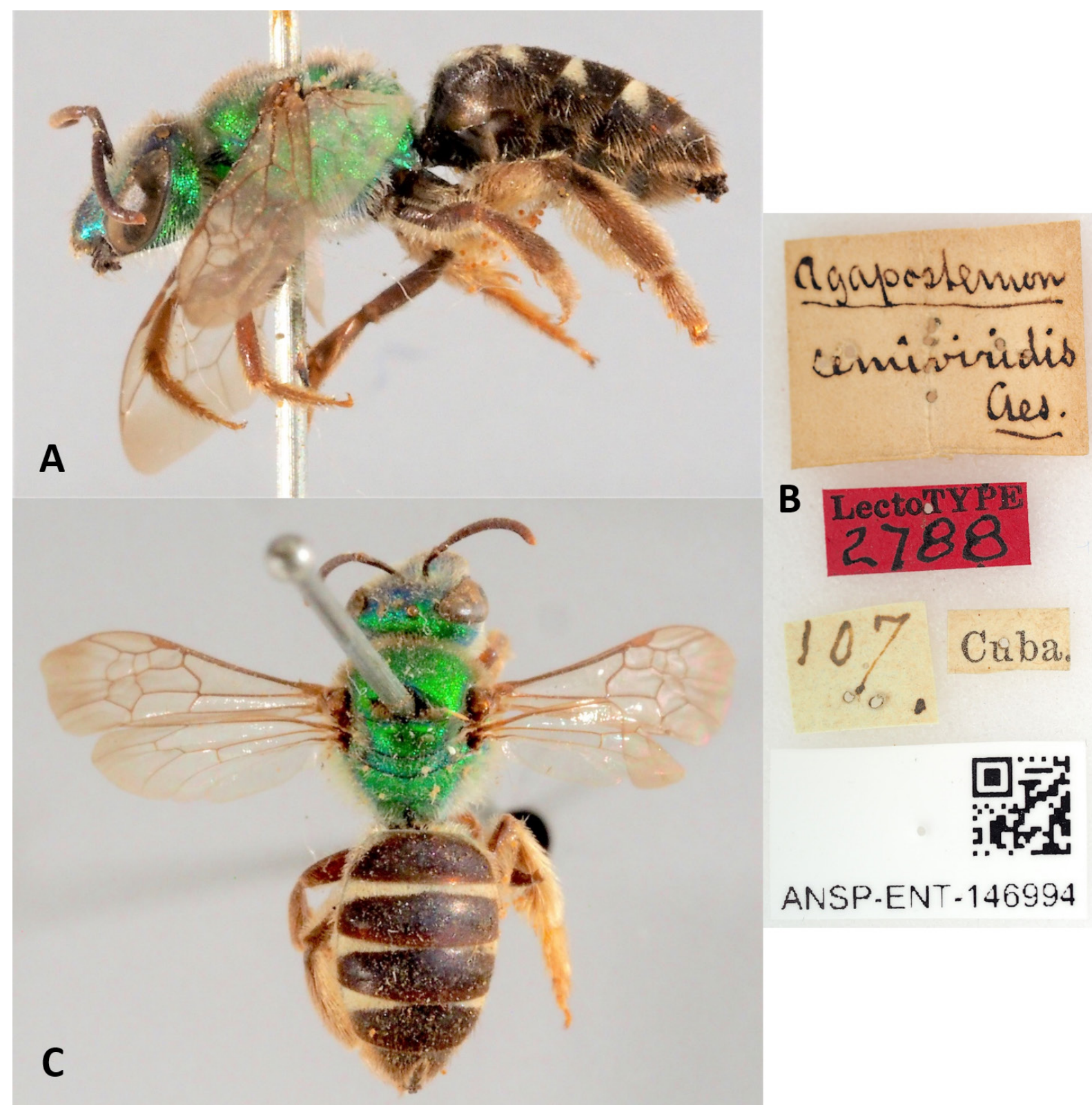

Fig. 4. Agapostemon semiviridis Cresson, 1865. Lectotype, ${ }_{+}$(ANSP 2788). A. Lateral view. B. Associated labels. C. Dorsal view. Photos by J.D. Weintraub/ANSP Entomology. 
indicating that the volume dedicated to insects (i.e., Guérin-Méneville 1844a) is dated 1829-1838 with many references to other dates within the text, including 1844, the year most researchers have used in citing this work (e.g., Roberts 1972; Michener 2000, 2007, though Moure (1960) indicated 1845). However, as Cuvier's original plates were published in 1837 (Cuvier 1837), Banks (1909) felt that those of the opinion

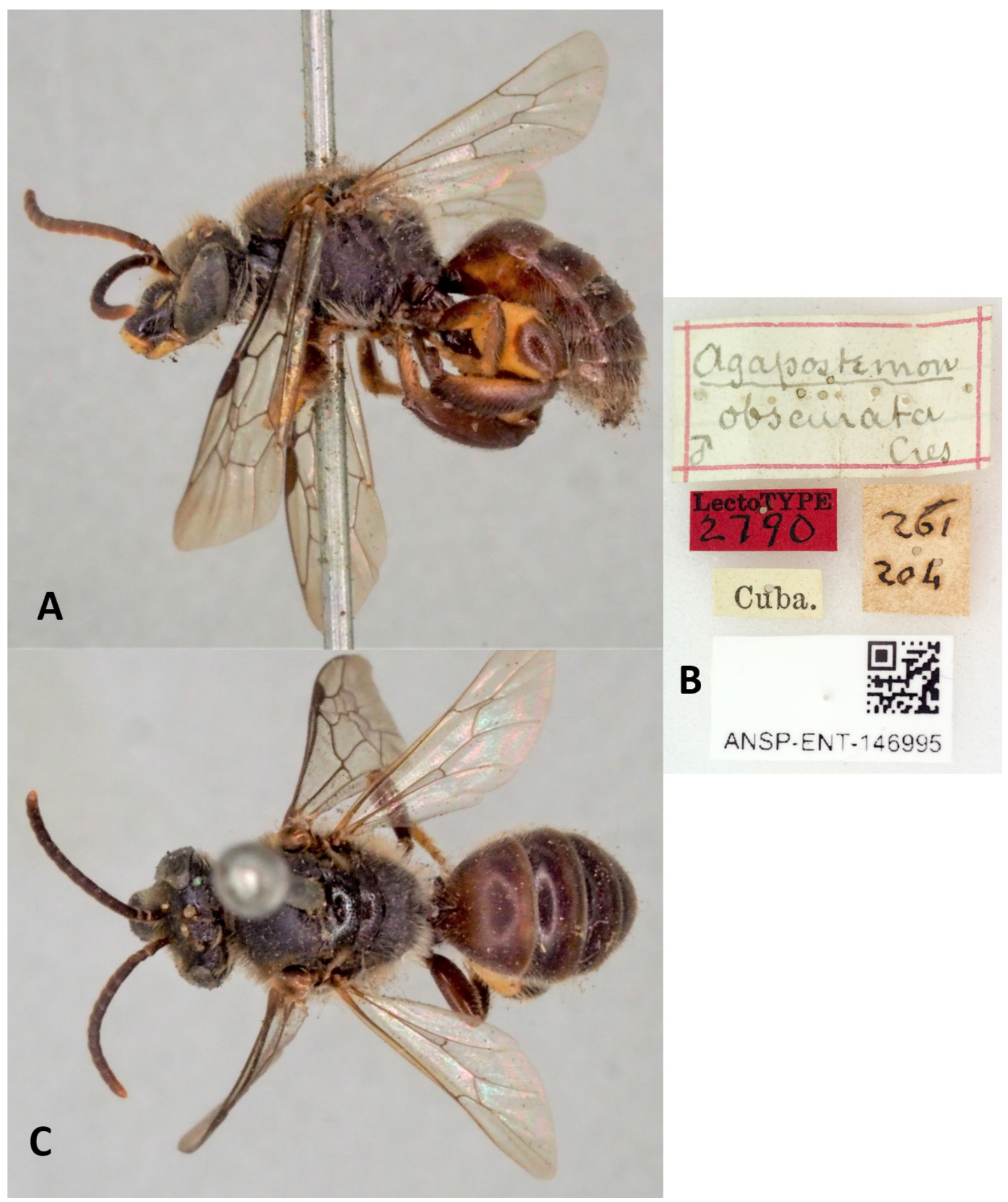

Fig. 5. Agapostemon obscuratus Cresson, 1869. Lectotype, ô (ANSP 2790). A. Lateral view. B. Associated labels. C. Dorsal view. Photos by J.D. Weintraub/ANSP Entomology. 
"that a named figure is valid without [accompanying] text must credit such names" with the dates of the plate publication. However, Cowan (1971) more recently reviewed the issue of Guérin-Méneville's works and concluded that the date relevant to the insects is 1844 , and this decision is followed here.

Van der Vecht (1957) examined material that he assumed was part of the type material for Ag. femoralis at the Rijksmuseum van Natuurlijke Historie, Leiden (now Naturalis Biodiversity Center, Leiden), though he also indicated the possibility of syntypes existing at other institutions; other specimens with the same collection information exist at Naturalis Biodiversity Center. Thus, to stabilize Ag. femoralis as the valid name of this Cuban taxon, the specimen Van der Vecht (1957) provided details on (i.e., fig. 3) is hereby selected as the lectotype. Incidentally, Ag. femoralis is the type species for the genus Agapostemon

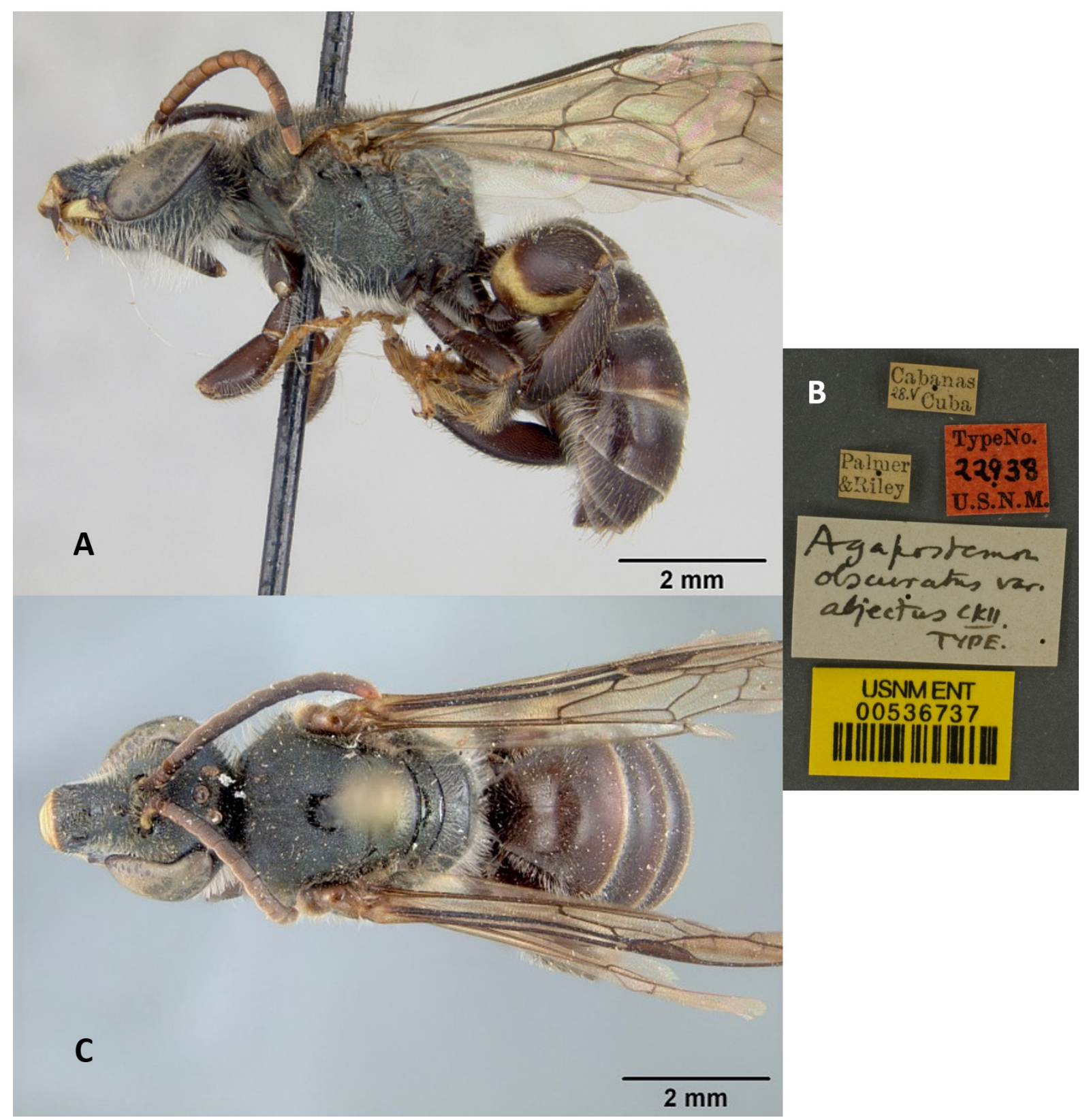

Fig. 6. Agapostemon obscuratus var. abjectus Cockerell, 1917. Holotype, đ̊ (USNM 22938). A. Lateral view. B. Associated labels. C. Dorsal view. Photos by USNM. 

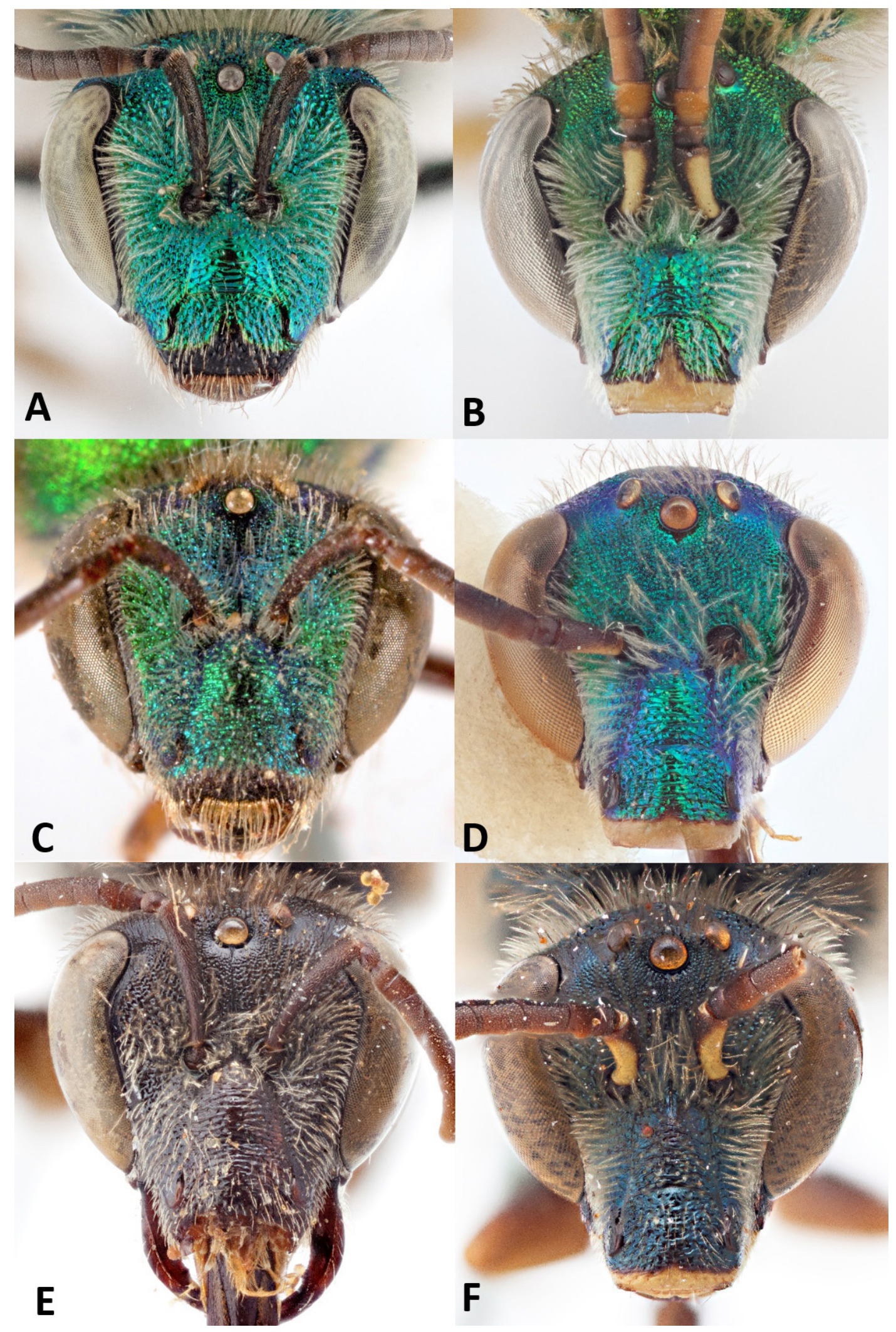

Fig. 7. Face of females (left column) and males (right column). A-B. Agapostemon virescens (Fabricius, 1775). C. Ag. semiviridis Cresson, 1865, lectotype [= Ag. femoralis (Guérin-Méneville, 1844)]. D. Ag. femoralis. E-F. Ag. obscuratus Cresson, 1869; note, the apex of clypeus of female is damaged. 
(Sandhouse 1936, 1943; Michener 1997). Dalla Torre (1896) was the first to treat Ag. femoralis as a synonym of Ag. viridulus (later followed by Friese 1902), though the assumption that the type material of $\mathrm{Ag}$. viridulus was collected in Cuba was baseless.

The female type material of Halictus cubensis Spinola was not an Agapostemon, but rather Augochlora regina Smith, 1853 (Augochlorini) (Engel 2004), so Engel (2004) designated the male as a lectotype, and placed it into synonymy with Ag. femoralis. However, as a result of this designation, Ag. cubensis Roberts became a junior secondary homonym of $\mathrm{Ag}$. cubensis (Spinola), thus requiring the replacement name provided below.

Though Roberts (1972) records the synonymy of Ag. semiviridis Cresson under Ag. viridulus as new, Baker (1906) had already treated it as a synonym. When described, Cresson (1865) indicated that it was potentially the female of $\mathrm{Ag}$. viridulus.

\section{Agapostemon (Agapostemon) robertsi nom. nov.}

Agapostemon cubensis Roberts, 1972: 478 [§̋] [preoccupied, not Ag. cubensis (Spinola) = Ag. femoralis (Guérin-Méneville, 1844)].

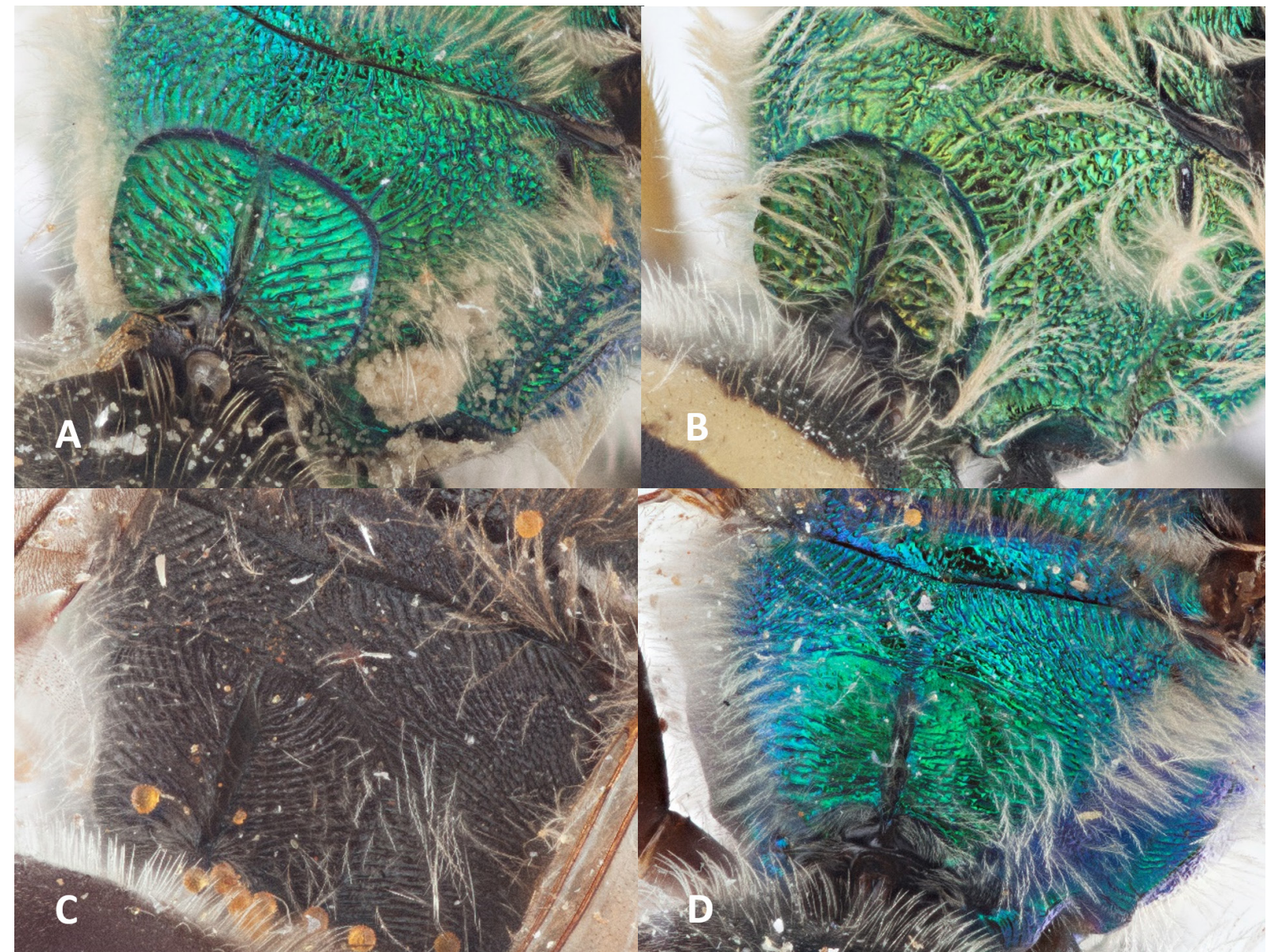

Fig. 8. Propodeum. A-B. Agapostemon virescens (Fabricius, 1775),, (A) and $\widehat{\partial}(\mathrm{B})$, showing distinctive carina encircling posterior surface. C. Ag. obscuratus Cresson, 1869, ㅇ [= Ag. femoralis (GuérinMéneville, 1844)]. D. Ag. femoralis, $\widehat{\jmath}$, with weak carina that does not encircle posterior surface. 


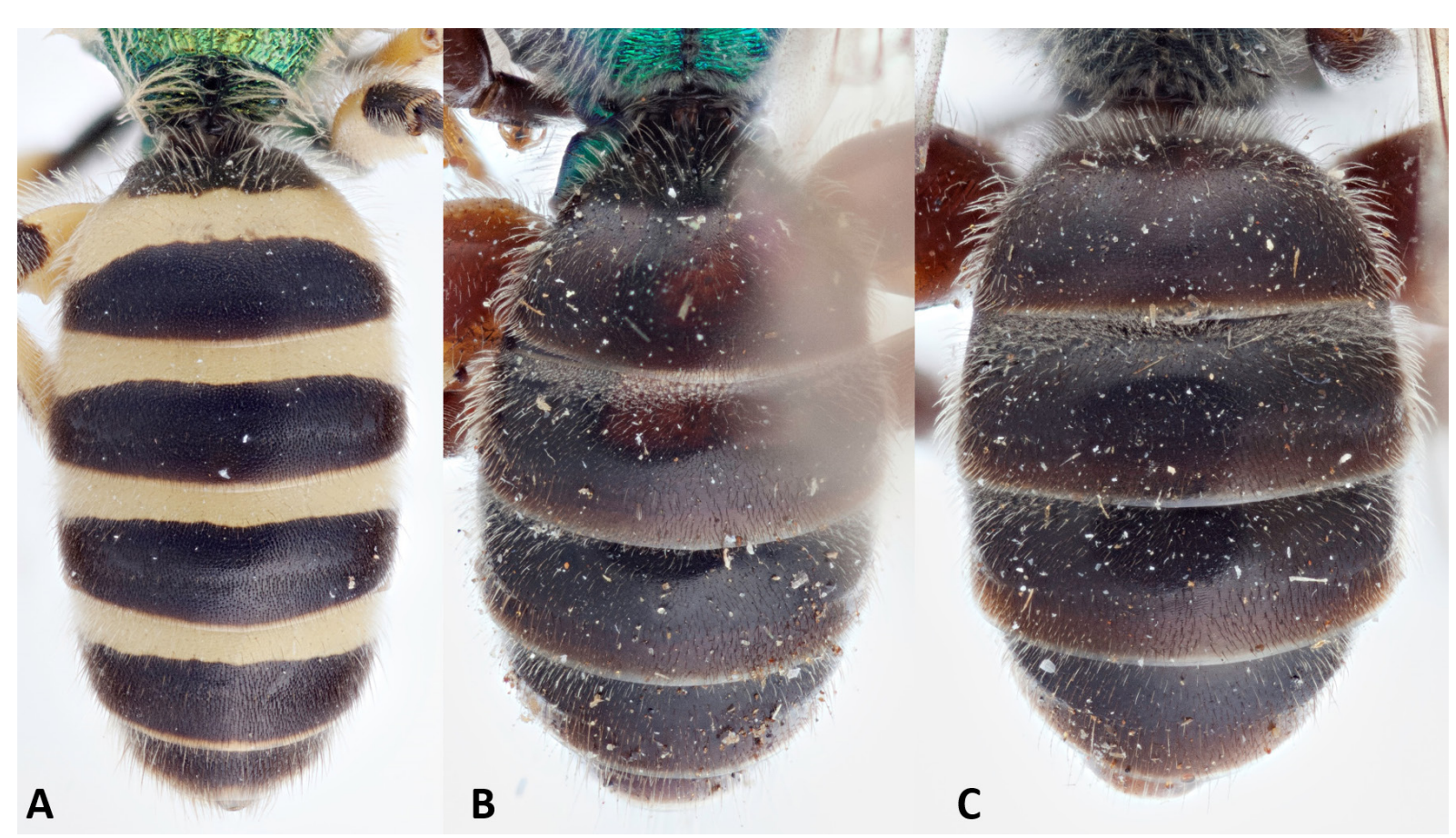

Fig. 9. Dorsal view of the metosoma of male. A. Agapostemon virescens (Fabricius, 1775). B. Ag. femoralis (Guérin-Méneville, 1844). C. Ag. obscuratus Cresson, 1869 [= Ag. femoralis].

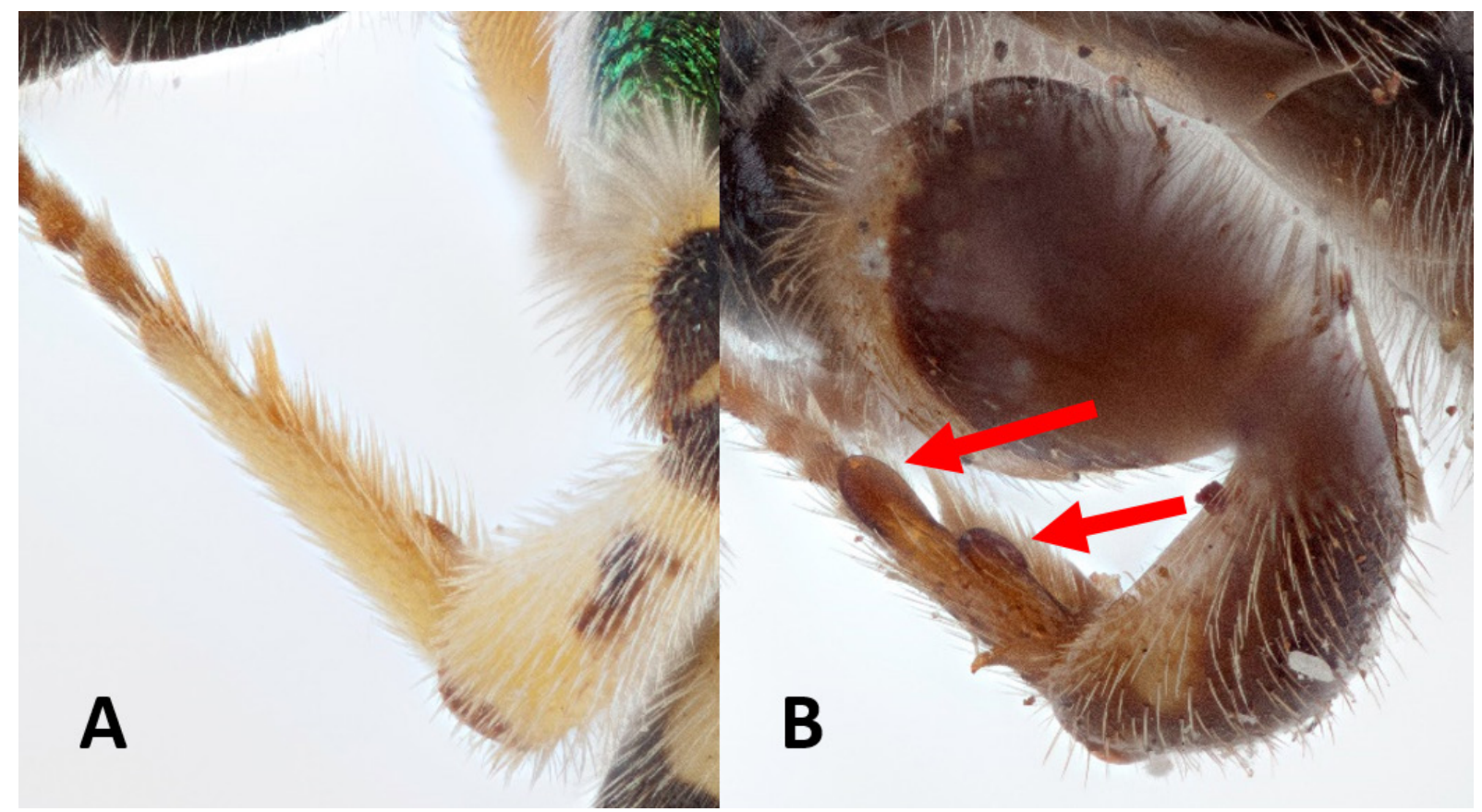

Fig. 10. Hind basitarsus of male. A. Agapostemon virescens (Fabricius, 1775), which is unmodified. B. Ag. femoralis (Guérin-Méneville, 1844), with upper arrow showing the prominent apical groove, and the lower arrow showing the prominent basal ridge. 


\section{Notes}

The holotype ${ }^{\lambda}$ of Ag. robertsi, from Cuba, "5.K. S. of Pinar Rio" [Pinar del Río], "12-23 September '13", AMNH, did not need to be examined.

\section{Discussion}

Though previous workers assumed that the type material of Ag. viridulus was from, and presumably endemic to Cuba (e.g., Dalla Torre 1896; Ashmead 1900; Cockerell 1910; Moure 1960; Roberts 1972), there is no evidence that this is true. In fact, in Fabricius's collected works there is only one bee species that was described with a type locality from Cuba, Coelioxys tridentata (Fabricius, 1775) [described as Apis tridentata] (Genaro 2006). As indicated by Genaro (2006), most early works on bees in the area are generally identified as coming from "Americae Meridionalis Insulis" (includes Cuba and/or another Caribbean island). Thus, it is hard to believe that Fabricius would have provided a specific locality for a species from Cuba in an earlier work (Fabricius 1775), though not for a species described in 1793 for which no locality was recorded until done so in 1804 (Fabricius 1804). However, it is also likely that detailed information was lacking for many of the specimens that Fabricius received from the Western Hemisphere.

Within the BIN to which $A g$. virescens belongs, there is little genetic variation, though members differ by over $12 \%$ from $\mathrm{Ag}$. femoralis, suggesting that although these species were considered morphologically very similar by Roberts (1972), there is enough genetic and morphological divergence to distinguish the species. The COI sequence of $\mathrm{Ag}$. obscuratus, also from Cuba, is genetically identical to material now recognized as Ag. femoralis. The phylogeny of Janjic \& Packer (2003) recovered Ag. femoralis [as Ag. viridulus] and Ag. obscuratus as separate taxa, albeit within the same species group, suggesting that a new phylogenetic analysis is warranted, though this was likely due in large part to colour differences between the material examined. Based on genetic similarity, shared geography, and past opinions of Cresson (1869) and Roberts (1972), we consider the taxon Ag. obscuratus to represent a colour polymorphic form of Ag. femoralis, and place it into synonymy. As Roberts (1972) synonymized Cockerell's (1917b) obscurely dark green (i.e., intermediate in colour; Fig. 6) taxon under Cresson's (1869), we assume he was also of the opinion that colour polymorphisms existed in Agapostemon. Though Roberts (1972) also considered the specific rank of $A g$. obscuratus questionable, he did not synonymize it under $A g$. viridulus despite noting only differences in colour between the two taxa. Such variation within a metallic bee species, ranging from metallic green or blue to black is uncommon, but not unheard of in bees. For instance, Osmia (Melanosmia) tersula Cockerell, 1912 (Megachilidae) is typically metallic blue in most of its range (Sandhouse 1939; Mitchell 1962), though black specimens lacking metallic colouration do occur (Rightmyer et al. 2010). Many metallic halictid bees show extensive congeneric (e.g., Gibbs 2010, 2011; Engel 2013, 2014a, 2014b) and conspecific (e.g., Ordway 1966) variation in body colouration; Ordway (1966) and Gibbs (2009) indicated that killing agents and other chemicals can alter metallic colouration to some extent. Combining molecular methods such as DNA barcoding to studies of bee taxonomy has proven very useful for recognizing colour variable species (e.g., Sheffield et al. 2011; Sheffield et al. 2020).

\section{Acknowledgements}

Thanks to Laurence Packer (York University, Toronto) for helpful discussion and comments on earlier drafts of this manuscript, and for loans of specimens; to Doug Yanega (University of California, Riverside) for advice and discussion of the ICZN code. Thanks to the institutions that have online resources available for type material examination, which was especially useful during the difficult times of COVID-19 - these include the BMNH and the USNM. Thanks to Jason Weintraub and Jon Gelhaus (Department of Entomology, Academy of Natural Sciences, Philadelphia) for providing photographs of 
type materials from (ANSP). The Biodiversity Heritage Library (https://www.biodiversitylibrary.org/) has continuously proven invaluable as a resource for the study of older, highly relevant taxonomic literature, and was used extensively while completing this work.

\section{References}

Abrams J. \& Eickwort G.C. 1980. Biology of the communal sweat bee Agapostemon virescens (Hymenoptera: Halictidae) in New York State. Search Agriculture 1: 1-20.

Abrams J. \& Eickwort G.C. 1981. Nest switching and guarding by the communal sweat bee Agapostemon virescens (Hymenoptera, Halictidae). Insectes Sociaux 28: 105-116. https://doi.org/10.1007/BF02223699

Alayo P. 1973. Catálogo de los Himenópteros de Cuba. Pueblo y Educación, La Habana.

Alayo P. 1976. Introducción al estudio de los himénopteros de Cuba. IX- Superfamilia Apoidea. Serie Biológica, Instituto de Zoología, Cuba 68: 1-35.

Ascher J.S. \& Pickering J. 2020. Discover Life bee species guide and world checklist (Hymenoptera: Apoidea: Anthophila). Available from http://www.discoverlife.org $/ \mathrm{mp} / 20 \mathrm{q}$ ?guide=Apoidea_species [accessed 21 Aug. 2020].

Ashmead W.H. 1896. Notes of the Hymenoptera. Collected by the Bahama Expedition from the State University of Iowa. Bulletin from the Laboratories of Natural History of the State University of Iowa 4: 28-32.

Ashmead W.H. 1900. VI. Report upon the aculeate Hymenoptera of the Islands of St. Vincent and Grenada, with additions to the parasitic Hymenoptera and a list of the described Hymenoptera of the West Indies. Transactions of the Entomological Society of London 2: 207-367.

https://doi.org/10.1111/j.1365-2311.1900.tb02379.x

Baker C.F. 1906. Halictinae de Cuba. In: Earle F.S. (ed.) Primer Informe Anual de la Estación Central Agronómica de Cuba: 253-274. La Universal de Ruiz y Hermano, Havana.

Banks N. 1909. Dates of Guérin's Iconographie du Regne Animali. Entomological News 20: 396-397.

Cockerell T.D.A. 1902. Flowers and insects in New Mexico. The American Naturalist 36: 809-817. https://doi.org/10.1086/278219

Cockerell T.D.A. 1904. IV.-Descriptions and records of bees. Annals and Magazine of Natural History Series 714 (79): 21-30. https://doi.org/10.1080/03745480409442962

Cockerell T.D.A. 1909. II.-Descriptions and records of bees.-XXI. Annals and Magazine of Natural History Series 84 (19): 25-31. https://doi.org/10.1080/00222930908692634

Cockerell T.D.A. 1910. Some neotropical bees. Psyche 17: 142-144. https://doi.org/10.1155/1910/35751

Cockerell T.D.A. 1911. Records of bees. The Canadian Entomologist 43: 389-391.

https://doi.org/10.4039/Ent43389-11

Cockerell T.D.A. 1917a. XXV.-Descriptions and records of bees.-LXXVI. Annals and Magazine of Natural History Series 820 (117): 235-241. https://doi.org/10.1080/00222931709486998

Cockerell T.D.A. 1917b. LIV.-Descriptions and records of bees.-LXXVIII. Annals and Magazine of Natural History Series 820 (120): 436-441. https://doi.org/10.1080/00222931709487033

Cockerell T.D.A. 1921. XXXV.-Descriptions and records of bees.-XCI. Annals and Magazine of Natural History Series 98 (45): 359-368. https://doi.org/10.1080/00222932108632595

Cowan C.F. 1971. On Guérin's Iconographie: particularly the insects. Journal of the Society for the Bibliography of Natural History 6: 18-29. https://doi.org/10.3366/jsbnh.1971.6.1.18 
Crawford J.C. 1901. North American bees of the genus Agapostemon Guérin. Proceedings of the Nebraska Academy of Sciences 7: 156-165.

Crawford J.C. 1912. Notes on some Canadian bees. The Canadian Entomologist 44: 359-360. https://doi.org/10.4039/Ent44359-12

Cresson E.T. 1865. On the Hymenoptera of Cuba. Proceedings of the Entomological Society of Philadelphia 4: 1-200.

Cresson E.T. 1869. Notes on Cuban Hymenoptera, with descriptions of new species. Transactions of the American Entomological Society 2: 293-298. https://www.jstor.org/stable/25076211

Cresson E.T. 1887. Synopsis of the families and genera of the Hymenoptera of America, north of Mexico, together with a catalogue of the described species, and bibliography. Transactions of the American Entomological Society Supplementary Volume: i, iii-vi, 1-350. https://doi.org/10.5962/bhl.title.38716

Cresson E.T. 1916. The Cresson types of Hymenoptera. Memoirs of the American Entomological Society 1: 1-141. https://doi.org/10.5281/zenodo.26375

Cuvier G. 1836. The Animal Kingdom, Arranged According to its Organization, Serving as a Foundation for the Natural History of Animals, and an Introduction to Comparative Anatomy. Vol. IV. G. Henderson, London. [text].

Cuvier G. 1837. The Animal Kingdom, Arranged According to its Organization, Serving as a Foundation for the Natural History of Animals, and an Introduction to Comparative Anatomy. Vol. IV. InsectaZoophytes. G. Henderson, London. [plates].

Dalla Torre C.G. 1896. Catalogus Hymenopterorum hucusque descriptorum systematicus et synonymicus. Vol. 10. Guilelmi Engelmann, Leipzig [Lipsiae]. https://doi.org/10.5962/bhl.title.10348

Ebmer A.W. 1974. Von Linné bis Fabricius beschriebene westpaläarktische Arten der Genera Halictus und Lasioglossum (Halictidae, Apoidea). Nachrichtenblatt der Bayerischen Entomologen 23: 111-127.

Eickwort G.C. 1981. Aspects of the nesting biology of five Nearctic species of Agapostemon (Hymenoptera: Halictidae). Journal of the Kansas Entomological Society 54: 337-351. https://www.jstor.org/stable/25084166

Eickwort G.C. \& Abrams H. 1980. Parasitism of sweat bees in the genus Agapostemon by cuckoo bees in the genus Nomada (Hymenoptera, Halictidae, Anthorphoridae). The Pan-Pacific Entomologist 56: $144-152$.

Engel M.S. 2004. On the identity of Halictus cubensis Spinola, 1851 (Hymenoptera: Halictidae). Entomological News 115: 169-170.

Engel M.S. 2013. The bee genus Ischnomelissa in Peru, with a key to the species (Hymenoptera: Halictidae). Journal of Melittology 23: 1-5. https://doi.org/10.17161/jom.v0i23.4641

Engel M.S. 2014a. The bee genus Caenaugochlora in Venezuela (Hymenoptera: Halictidae). Journal of Melittology 33: 1-10. https://doi.org/10.17161/jom.v0i33.4725

Engel M.S. 2014b. Three new species of the genus Caenaugocholora from Central America and Columbia (Hymenoptera: Halictidae). Journal of Melittology 41: 1-15.

https://doi.org/10.17161/jom.v0i41.4810

Fabricius J.C. 1775. Systema Entomologiae. Libraria Kortii, Flensburg and Leipzig [Flensbergi et Lipsiae]. https://doi.org/10.5962/bhl.title.36510

Fabricius J.C. 1793. Entomologia Systematica, 2. Copenhagen [Hafniae].

https://doi.org/10.5962/bhl.title.122153 
Fabricius J.C. 1804. Systema Piezatorum. Brunswick [Brunsvigae]. https://doi.org/10.5962/bhl.title.10490

Fischer R.L. 1950. Kansas bees of the genus Agapostemon Guerin (Hymenoptera, Halictidae). Journal of the Kansas Entomological Society 23: 76-78. https://www.jstor.org/stable/25081922

Friese H. 1902. Beitrag zur Apidenfauna der grossen Antillen. Zeitschrift für systematische hymenopterologie und dipterologie 2: 196-201.

Genaro J.A. 2006. A history of systematic studies of the bees of Cuba (Insecta: Hymenoptera, Anthophila). Zootaxa 1195: 39-60. https://doi.org/10.11646/zootaxa.1195.1.3

Genaro J.A. 2008. Origins, composition and distribution of the bees of Cuba (Hymenoptera: Apoidea: Anthophila). Insecta Mundi 52:1-16.

Gibbs J. 2009. New species in the Lasioglossum petrellum species group identified through an integrative taxonomic approach. The Canadian Entomologist 141: 371-396. https://doi.org/10.4039/n09-020

Gibbs J. 2010. Revision of the metallic species of Lasioglossum (Dialictus) in Canada (Hymenoptera, Halictidae, Halictini). Zootaxa 2591: 1-382. https://doi.org/10.11646/zootaxa.2591.1.1

Gibbs J. 2011. Revision of the metallic Lasioglossum (Dialictus) of eastern North America (Hymenoptera: Halictidae: Halictini). Zootaxa 3073: 1-216. https://doi.org/10.11646/zootaxa.3073.1.1

Guérin-Méneville F.E. 1844a. Iconographie du Règne Animal de G. Cuvier, ou représentation d'après nature de l'une des espèces les plus remarquables, et souvent non encore figurées de chaque genre d'animaux. Insectes. [1829-1838]. J.B. Baillière, Paris. [text]. https://doi.org/10.5962/bhl.title.10331

Guérin-Méneville F.E. 1844b. Iconographie du Règne Animal de G. Cuvier, ou représentation d'après nature de l'une des espèces les plus remarquables, et souvent non encore figurées de chaque genre d'animaux. Tome II. Planches des Animaux invertébrés. [1829-1844]. J.B. Baillière, Paris. [plates].

Gundlach J.C. 1896. Contribución a la Entomología Cubana. Tomo II. G. Montiel, Habana. https://doi.org/10.5962/bhl.title.49760

Harris M. 1782. An Exposition of English Insects. London. https://doi.org/10.5962/bhl.title.168994

Harris R.A. 1979. A glossary of surface sculpturing. Occasional Papers in Entomology 28: 1-31.

Hebert P.D.N., Cywinska A., Ball S.L. \& deWaard J.R. 2003. Biological identifications through DNA barcodes. Proceedings of the Royal Society B: Biological Sciences 270 (1512): 313-322.

https://doi.org/10.1098/rspb.2002.2218

Janjic J. \& Packer L. 2003. Phylogeny of the bee genus Agapostemon (Hymenoptera: Halictidae). Systematic Entomology 28: 101-123. https://doi.org/10.1046/j.1365-3113.2003.00204.x

Krombein K.V. 1953. The wasps and bees of the Bimini island group, Bahamas, British West Indies (Hymenoptera, Aculeata). American Museum Novitates 1633: 1-29. Available from http://hdl.handle.net/2246/4931 [accessed 29 Apr. 2021].

LaBerge W.E. \& Ribble D.W. 1966. The nests and larvae of two species of Agapostemon (Hymenoptera: Halictidae). Journal of the Kansas Entomological Society 39: 467-472.

https://www.jstor.org/stable/25083542

Lepeletier A.L.M. 1841. Histoire Naturelle des Insectes - Hyménoptères. II. Roret, Paris. https://doi.org/10.5962/bhl.title.9005

Michener C.D. 1997. Genus-group names of bees and supplemental family-group names. Scientific Papers of the Natural History Museum, The University of Kansas 1: 1-81.

https://doi.org/10.5962/bhl.title.4052 
Michener C.D. 2000. The Bees of the World. Johns Hopkins University Press, Baltimore.

Michener C.D. 2007. The Bees of the World. Second Edition. Johns Hopkins University Press, Baltimore.

Mitchell T.B. 1962. Bees of the eastern United States, Volume 2. North Carolina Agricultural Experiment Station Technical Bulletin 152: 1-557.

Moure J.S. 1960. Notes on the types of Neotropical bees described by Fabricius (Hymenoptera: Apoidea). Studia Entomologica 3: 97-160.

Moure J.S. \& Hurd P.D. 1987. An Annotated Catalog of the Halictid Bees of the Western Hemisphere (Hymenoptera: Halictidae). Smithsonian Institution Press, Washington.

Moure J.S., Urban D. \& Melo G.A.R. (eds) 2007. Catalogue of bees (Hymenoptera, Apoidea) in the Neotropical Region. Sociedade Brasileira de Entomologia, Curitiba.

Ordway E. 1966. Systematics of the genus Augochlorella (Hymenoptera, Halictidae) north of Mexico. The University of Kansas Science Bulletin 46: 509-624. https://doi.org/10.5962/bhl.part.20079

Packer L., Genaro J.A. \& Sheffield C.S. 2007. The bee genera of eastern Canada. Canadian Journal of Arthropod Identification 3: 1-32. https://doi.org/10.3752/cjai.2007.03

Provancher L. 1882. Faune Canadienne. Les Insectes Hyménoptères. Naturaliste canadien 13: 193-209.

Ramírex-Freire L., Alanís-Flores G.J., Ayala-Barajas R., Quiroz-Martínez H. \& Velazco-Macías C.J. 2012. Las abejas del género Agapostemon (Hymenoptera: Halictidae) del estado de Nuevo León, México. Revista Mexicana de Biodiversidad 83: 63-72. https://doi.org/10.22201/ib.20078706e.2012.1.1143

Ratnasingham S. \& Hebert P.D.N. 2007. BOLD: The Barcode of Life Data System (www.barcodinglife. org). Molecular Ecology Notes 7: 355-364. https://doi.org/10.1111/j.1471-8286.2007.01678.x

Ratnasingham S. \& Hebert P.D.N. 2013. A DNA-based registry for all animal species: the barcode index number (BIN) system. PLoS ONE 8 (7): e66213. https://doi.org/10.1371/journal.pone.0066213

Rightmyer M.G., Griswold T. \& Arduser M.S. 2010. A review of the non-metallic Osmia (Melanosmia) found in North America, with additional notes on palearctic Melanosmia (Hymenoptera, Megachilidae). ZooKeys 60: 37-77. https://doi.org/10.3897/zookeys.60.484

Roberts R.B. 1972. Revision of the bee genus Agapostemon (Hymenoptera: Halictidae). The University of Kansas Science Bulletin 49: 437-590.

Roberts R.B. 1973. Bees of Northwestern America: Agapostemon (Hymenoptera: Halictidae). Agricultural Experiment Station, Oregon State University, Corvallis.

Roberts R.B. \& Brooks R.W. 1987. Agapostemonine bees of Mesoamerica (Hymenoptera: Halictidae). The University of Kansas Science Bulletin 53: 357-392.

Robertson C. 1893. Notes on bees, with descriptions of new species. Transactions of the American Entomological Society 20: 145-149. http://www.jstor.org/stable/25076604

Robertson C. 1895. Notes on bees, with descriptions of new species. Transactions of the American Entomological Society 22: 115-128. https://www.jstor.org/stable/25076640

Robertson C. 1897. North American bees - descriptions and synonyms. Transactions of the Academy of Science of St. Louis 7: 315-356.

Sandhouse G.A. 1936. The bees of the genus Agapostemon (Hymenoptera: Apoidea) occurring in the United States. Journal of the Washington Academy of Sciences 26: 70-83.

Sandhouse G.A. 1939. The North American bees of the genus Osmia. Memoirs of the Entomological Society of Washington 1: 1-167. 
Sandhouse G.A. 1943. The type species of the genera and subgenera of bees. Proceedings of the United States National Museum 92: 519-619. https://doi.org/10.5479/si.00963801.3156.519

Sheffield C.S. \& Perron J.-M. 2014. Annotated catalogue of the bees described by Léon Provancher (Hymenoptera: Apoidea). The Canadian Entomologist 146: 117-169. https://doi.org/10.4039/tce.2013.64

Sheffield C.S., Hebert P.D.N., Kevan P.G. \& Packer L. 2009. DNA barcoding a regional bee (Hymenoptera: Apoidea) fauna and its potential for ecological studies. Molecular Ecology Resources 9: 196-207. https://doi.org/10.1111/j.1755-0998.2009.02645.x

Sheffield C.S., Ratti C., Packer L. \& Griswold T. 2011. Leafcutter and mason bees of the genus Megachile Latreille (Hymenoptera: Megachilidae) in Canada and Alaska. Canadian Journal of Arthropod Identification 18: 1-107.

Sheffield C.S., Heron J., Gibbs J., Onuferko T.M., Oram R., Best L., deSilva N., Dumesh S., Pindar A. \& Rowe G. 2017. Contribution of DNA barcoding to the study of the bees (Hymenoptera: Apoidea) of Canada: progress to date. The Canadian Entomologist 149: 736-754. https://doi.org/10.4039/tce.2017.49

Sheffield C.S., Oram R. \& Heron J.M. 2020. Bombus (Pyrobombus) johanseni Sladen, 1919, a valid North American bumble bee species, with a new synonymy and comparisons to other "red-banded" bumble bee species in North America (Hymenoptera, Apidae, Bombini). ZooKeys 984: 59-81.

https://doi.org/10.3897/zookeys.984.55816

Shelford V.E. 1913. Animal Communities in Temperate America as Illustrated in the Chicago Region. The Geographic Society of Chicago by the University of Chicago Press, Chicago. https://doi.org/10.5962/bhl.title.34437

Shelford V.E. 1937. Animal Communities in Temperate America as Illustrated in the Chicago Region. Second Edition. The Geographic Society of Chicago by the University of Chicago Press, Chicago. https://doi.org/10.5962/bhl.title.7231

Smith F. 1853. Catalogue of Hymenopterous Insects in the Collection of the British Museum. British Museum, London. https://doi.org/10.5962/bhl.title.20858

Spinola M. 1851. Himenópteros. In: Gay C. (ed.) Historia Física y Política de Chile, Zoología [volumen 6]: 153-569. Maulde et Renou. https://doi.org/10.5962/bhl.title.16172

Stevens O.A. 1920. Further notes on evening flowers, panurgine and halictine bees. The Canadian Entomologist 53: 65-69. https://doi.org/10.4039/Ent5365-3

Titus E.S.C. 1900. Notes on Colorado bees. The Canadian Entomologist 32: 303-305.

https://doi.org/10.4039/Ent32303-10

Tucker E.S. 1909. Additional results of collecting insects in Kansas and Colorado. Transactions of the Kansas Academy of Science 22: 276-304.

Vachal J. 1903. Étude sur les Halictus d'Amerique (Hym.). Miscellanea Entomologica 11: 89-104.

Van der Vecht J. 1957. On some Hymenoptera from the collection of Guérin-Méneville in the Leiden Museum. Zoologische Mededelingen 35: 21-31.

Available from https://repository.naturalis.nl/pub/317915 [accessed 28 Apr. 2021].

Viereck H.L., Cockerell T.D.A., Titus E.S.G., Crawford J.C. \& Swenk M.H. 1906. Synopsis of bees of Oregon, Washington, British Columbia and Vancouver. -V. The Canadian Entomologist 38: 297-304. https://doi.org/10.4039/Ent38297-9

Warncke K. 1973. Die unter dem Gattungsnamen Apis beschriebenen Bienen der Gattung Halictus (Apoidea, Hymenoptera) und Fixierung von Lectotypen weiterer von Fabricius beschriebener HalictusArten. Nachrichtenblatt der Bayerischen Entomologen 22: 23-26. 
Webb D.W. 1980. Primary insect types in the Illinois Natural History Survey Collection, exclusive of the Collembola and Thysanoptera. Bulletin of the Illinois Natural History Survey 32: 55-191. Available from https://www.biodiversitylibrary.org/part/79302 [accessed 14 May 2021].

Manuscript received: 1 December 2020

Manuscript accepted: 3 March 2021

Published on: 25 May 2021

Topic editor: Gavin Broad

Topic editor: Nesrine Akkari

Desk editor: Pepe Fernández

Printed versions of all papers are also deposited in the libraries of the institutes that are members of the EJT consortium: Muséum national d'histoire naturelle, Paris, France; Meise Botanic Garden, Belgium; Royal Museum for Central Africa, Tervuren, Belgium; Royal Belgian Institute of Natural Sciences, Brussels, Belgium; Natural History Museum of Denmark, Copenhagen, Denmark; Naturalis Biodiversity Center, Leiden, the Netherlands; Museo Nacional de Ciencias Naturales-CSIC, Madrid, Spain; Real Jardín Botánico de Madrid CSIC, Spain; Zoological Research Museum Alexander Koenig, Bonn, Germany; National Museum, Prague, Czech Republic. 